\title{
S.O.S. Souss: argan forest destruction in Morocco
}

\author{
Jesús Mellado
}

The Souss Valley in Morocco still has remnants of forest dominated by the argan tree, which is endemic to the Atlantic coast of north-west Africa. The tree is valued for its edible oil and its timber, and the argan forest ecosystem is rich in species. The forest has been exploited sustainably by man for thousands of years, but modern developments have destroyed or damaged much of it, especially in the lowlands. The author, who worked in the region for three years, is alarmed at the rapidly increasing destruction. He makes a plea for effective protection of the remaining argan forest and for a plan for its sustainable exploitation.

The Souss River, which seldom flows, passes over the alluvial plain between the High Atlas

and Anti-Atlas mountain ranges in south-west Morocco. The valley is closed at the east, where,

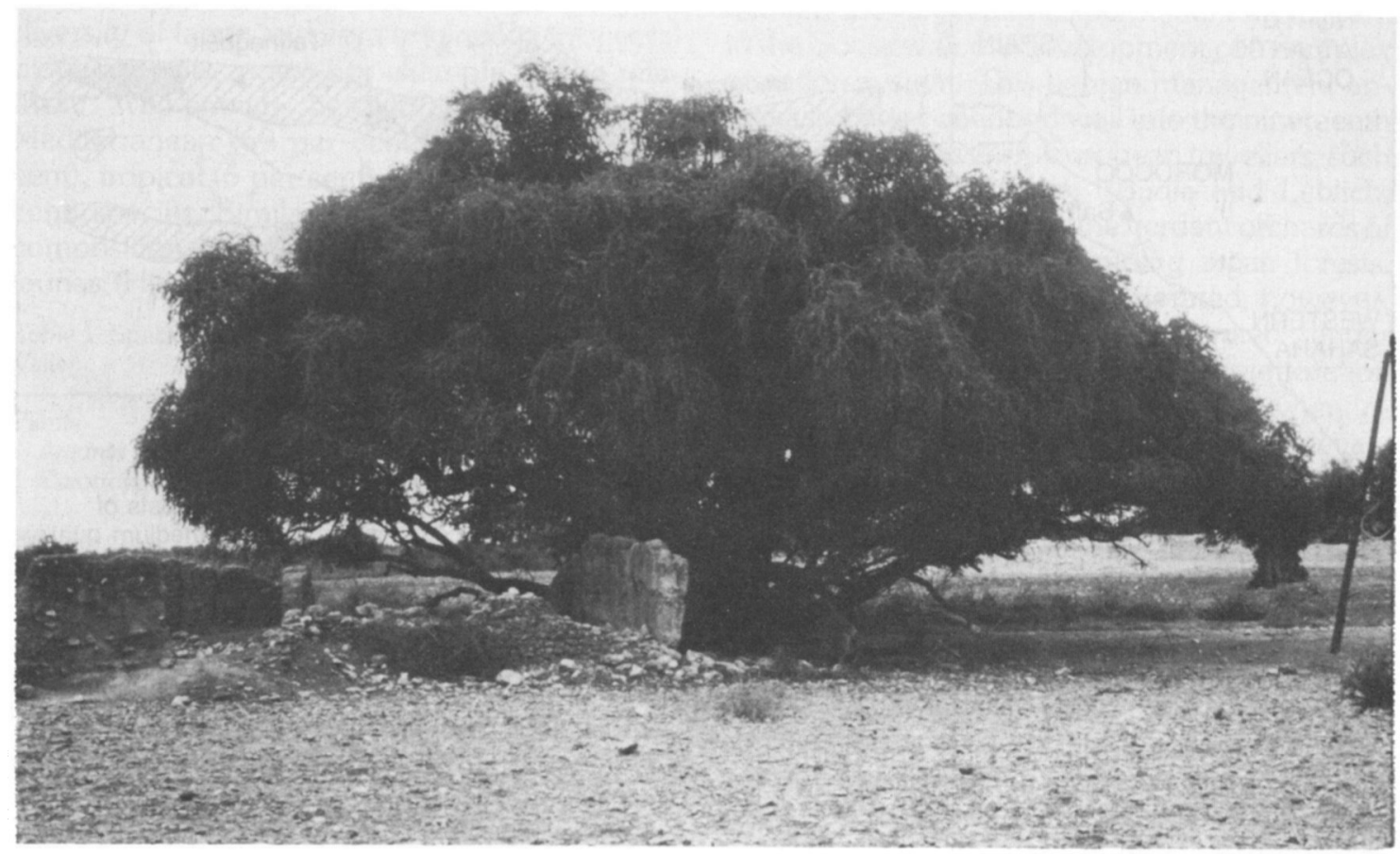

An old argan tree; the tallest specimens still remaining on the Souss plain are usually close to human habitation (J. Mellado). 
the mountain ranges meet, but is open to the Atlantic Ocean to the west (Figure 1). Consequently, the Souss plain and the smaller adjacent Massa Valley are protected from the extreme climatic conditions of the Sahara and benefit from more temperate oceanic influences. The climate of the Souss plain, therefore, is relatively mild, compared with neighbouring country at the same latitude, and has frequent fogs throughout the year. It falls within the range of arid Mediterranean bioclimates (Le Houérou, 1981).

The region has a wide variety of vegetation types, including marsh and cactus-like stands of spurge shrublands of Macaronesian origin, but the principal component of the vegetation is the argan tree Argania spinosa, which is a member of the tropical family Sapotaceae. This tree is the only species of one of the few genera of the family to reach the subtropical zone and is endemic to the Atlantic coast of north-west Africa. It is widely distributed from Safi to the Draa river
(Sauvage and Vindt, 1952) and isolated populations extend as far as Sagiat el Hamra, well inside the Western Sahara (Valverde, 1957). The altitudinal range of the tree extends from sea level up to $1500 \mathrm{~m}$. It is associated with a wide variety of plant species, but forms the dominant component of the vegetation (Peltier, 1976, 1977; Posner, 1986). Other trees growing with the argan include olive Olea europaea and mastic Pistacia lentiscus, and in sandy areas, Phoenicean juniper Juniperus phoenicea. On calcareous soils at sea level, it may be found with a spurge Euphorbia echinus. In the upper limits of its altitudinal range, the argan tree may co-exist with holm oak Quercus ilex and juniper Juniperus oxycedrus. It is, however, in the Souss Valley that the argan forest attains its greatest development as an ecosystem. This tree can grow to $10 \mathrm{~m}$ on the Souss plain and has a magnificent spreading form when unmanaged. It forms more than 50 per cent of the vegetation cover, with acacia Acacia gummifera and sumac Rhus

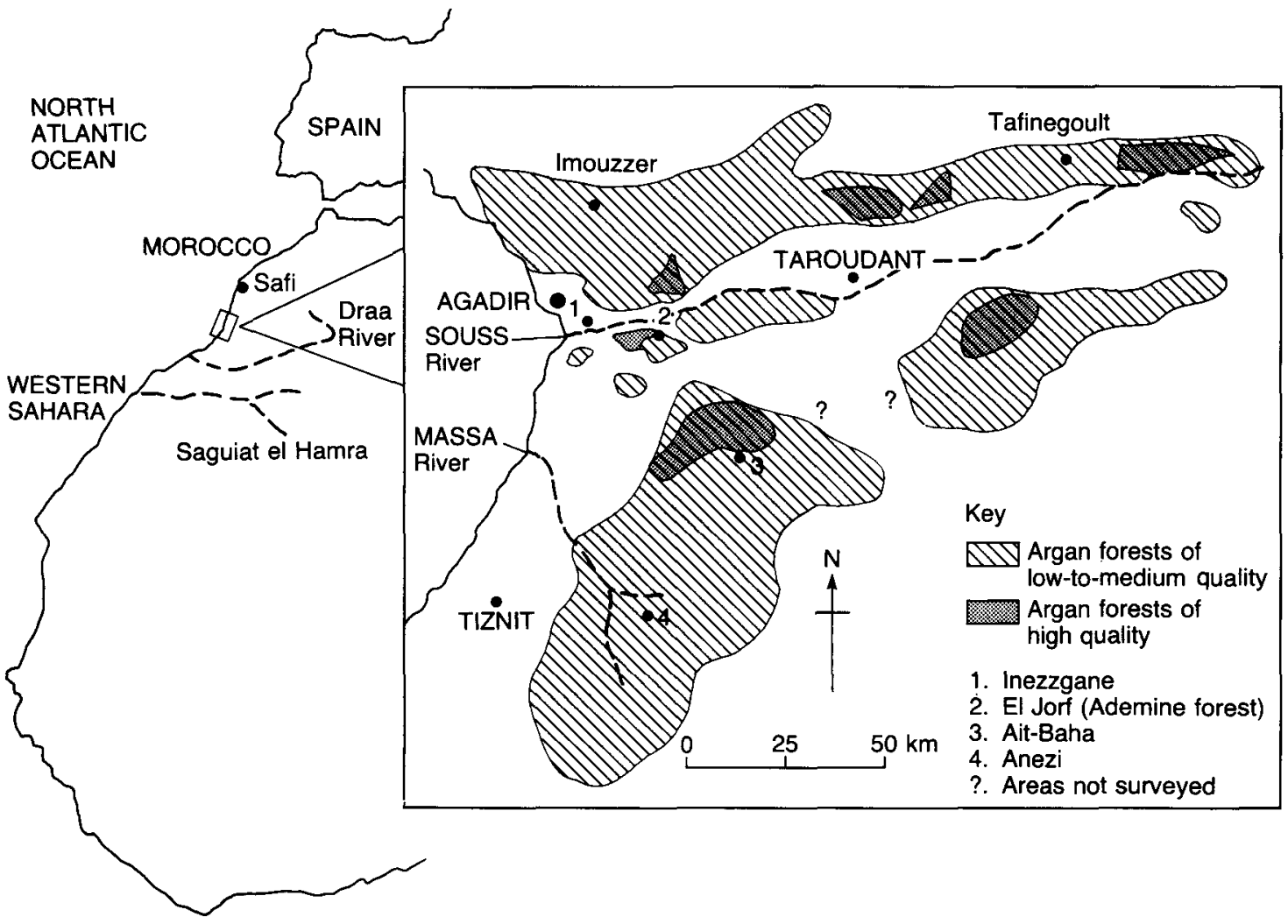

Figure 1. Tentative range of argan forest in the Souss today. 
tripartita as the principal associates. The undergrowth consists mainly of jujube Ziziphus lotus and woad-waxen Genista ferox, which often form impenetrable scrub. Consequently the argan forest resembles tropical thorn savannahs rather than Mediterranean forests.

\section{Peculiarities of the argan ecosystem}

Little is known about the composition, structure and function of the argan ecosystem, although passing mention has been made in general reviews of Mediterranean woodlands (MAB, 1976; Goodall and Perry, 1979; Di Castri, Goodall and Specht, 1981; Evenary, Noy-Meyr and Goodall, 1986). Available information suggests a wide ecological diversity in the Souss Valley. Plant species richness has been reported from three areas (Peltier, 1976, 1977; Posner, 1986) and preliminary surveys of the Massa Valley and surrounding regions list some 30 mammal and 240 bird species (Hirsch, 1981). About 40 amphibian and reptile species have been recorded in the Souss area (Bons, 1967, Mellado, unpubl.).

In addition to this species richness, the Souss shares with other Mediterranean regions a great diversity of fauna and flora originating in several biogeographic zones. For example, in the relatively well-known herpetofauna, there are Mediterranean (69 per cent), Saharan (15 per cent), tropical (6 per cent) and endemic (10 per cent) species. Similar proportions occur in the composition of birds, mammals and freshwater faunas (Hirsch, 1981). The majority of species,

Table 1. Species of tropical origin occurring in the Souss Valley

Plants

Argania spinosa Argan tree

Calotropa procera Calotrope

Reptiles

Boaedon fuliginosum Common African snake

Naja haje Egyptian cobra

Bitis arietans Puff adder

Birds

Melierax metabates Dark chanting goshawk

Mammals

Xerus erythropus Geoffroy's ground squirrel

Lemniscomys barbarus Zebra rat

Acomys spp. Spiny mice

Mellivora capensis Honey badger therefore, originate in the Palaearctic, although there is a strong endemic element, typical of Morocco, which is a well-known centre for speciation in the Mediterranean zone. The peculiarity of the Souss, however, lies mainly in the relative importance of the species of Macaronesian origin and the interesting remains of tropical origin including the argan tree itself, as well as snakes, birds and mammals (Table 1).

\section{Land use in the Souss}

\section{Background}

It is likely that the argan forest ecosystem has been exploited by man since the settlement of the ancestral Aryan tribes of the present Berber people some 3500-4000 BP. The nature of the exploitation is believed to have been very similar to the present-day traditional management of mountainous areas in the Souss. Such management was likely to have been light and diverted towards supplying food and fuel-wood for a sparse rural population. The settlement of Arab people in Berbery during the seventh century $\mathrm{AD}$ marked the beginning of permanent agriculture in the Souss with the development of a complex irrigation system. This benign management appears to have continued well into the nineteenth century when the early European travellers, such as the so-called 'Ali-Bey' (Badia and Leblich, 1814) were impressed by the verdant orchards of Taroudant and the surrounding argan forests. Conditions in the Souss deteriorated, however, when development was accelerated under French rule from 1912. Further deterioration occurred after independence in 1956, when increased human impact led to widespread devastation, which continues today.

\section{The Souss today}

Two quite different kinds of land use are practised in the Souss, the traditional and the modern. Table 2 summarizes the main features of both types of management. Traditional management is now restricted to mountainous regions, with the exploitation of the argan forest for argan oil (a fine table oil), cattle, firewood and occasional clearance for cereal growing. At worst, this type of management results in the formation of a semi-natural, park-like woodland (Le Houérou, 
1981) similar to other Mediterranean parklands, such as the Spanish dehesas. Such management is conducive to the preservation of natural resources.

On the other hand, the modern development practised in the lowlands of the Souss and on the Atlantic coast is catastrophic. With the widespread settlement of large-scale irrigated cultivation in the Souss and Massa valleys since the 1960 s, significant areas of the better argan forest ecosystem have been cleared for crops and the remaining patches have been severely exploited for firewood and charcoal. The resulting pastures have been heavily over-grazed and where re-afforestation has taken place, exotic acacia trees have been planted. Consequently much of the argan forest has disappeared from the Souss lowland and the remaining stands are very fragmented and often heavily damaged.

This regrettable situation is even worse near the coast. After the earthquake of 1960, the town of Agadir was rebuilt as an important seaside tourist centre, so that tourist pressure has been added to the destructive impacts suffered by the Souss. In addition, the new town has attracted a rapidly growing human population from surrounding areas resulting in the great development of urban settlement along the road network. Most of the damage along the seashore is not to the argan forest, which is represented only by isolated patches inland, but to the dune system, which is already seriously affected by eucalyptus plant-

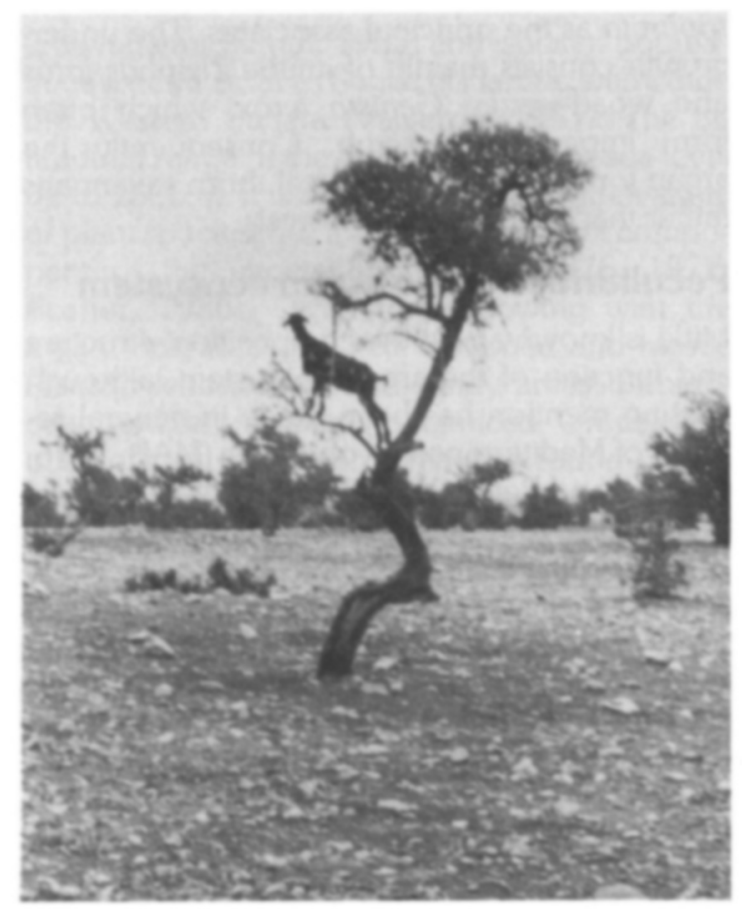

Argan forests are overgrazed by goats; tourists may exacerbate this indirectly by paying goat herders in order to photograph goats climbing trees (J. Mellado).

ing. Pollution has seriously affected the marshes of the Souss mouth. Nevertheless, the remaining argan patches are being damaged, including some of the finest, such as the well-known and formerly splendid Ademine Forest.

Table 2. Land uses in the Souss Valley today, with subjective assessment of the strength of the environmental impacts involved in both traditional and 'modern' management.

\begin{tabular}{|c|c|c|c|c|}
\hline Land uses & Traditional & Threat & Modern & Threat \\
\hline Agriculturalism & $\begin{array}{l}\text { Extensive } \\
\text { - Argan oil } \\
\text { - Occasional } \\
\text { cereal growing }\end{array}$ & Low & $\begin{array}{l}\text { Intensive } \\
\text { - Irrigated agriculture }\end{array}$ & Extreme \\
\hline Pastoralism & $\begin{array}{l}\text { Grazing } \\
\text { - Goats, sheep }\end{array}$ & $\begin{array}{l}\text { Medium to High } \\
\text { (occasional } \\
\text { overgrazing) }\end{array}$ & $\begin{array}{l}\text { Overgrazing } \\
\text { - Goats, sheep, } \\
\text { cows, camels }\end{array}$ & High to extreme \\
\hline Forestry & $\begin{array}{l}\text { Logging } \\
\text { - Fuelwood, } \\
\text { charcoal }\end{array}$ & Low to Medium & $\begin{array}{l}\text { Clear felling } \\
\text { - Logging } \\
\text { - Reafforestation }\end{array}$ & High to Extreme \\
\hline Tourism & - & - & $\begin{array}{l}\text { Overcrowding } \\
\text { - Urban settlements, } \\
\text { Road networks } \\
\text { - Pollution }\end{array}$ & Extreme (locally) \\
\hline
\end{tabular}




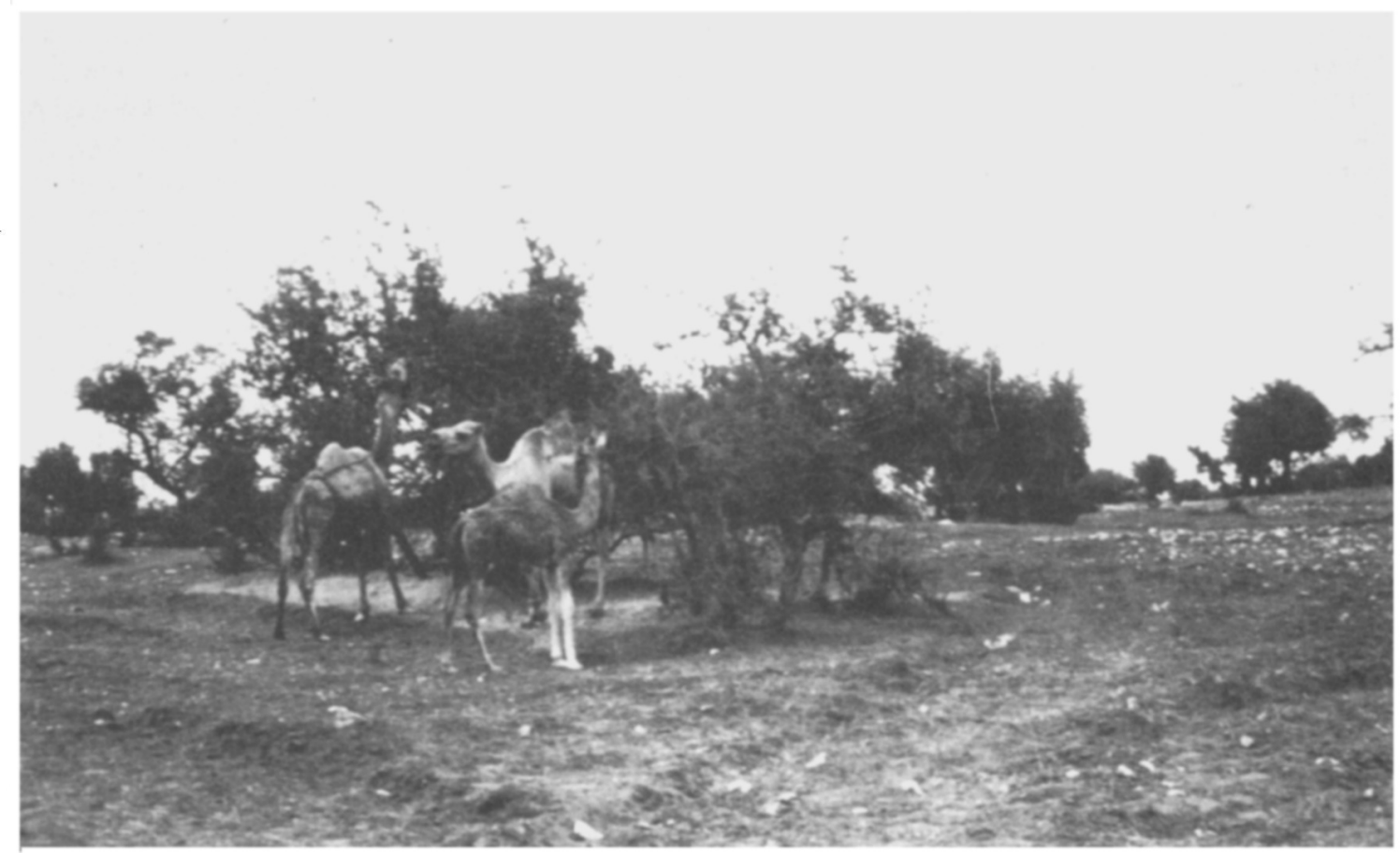

Above: Hundreds of camels from the Sahara contribute to the problem of over-grazing ( $J$. Mellado). Below: Well preserved argan forest still occurs in the foothills of the Atlas mountains, but the flatter areas in the foreground are severely damaged (J. Mellado).

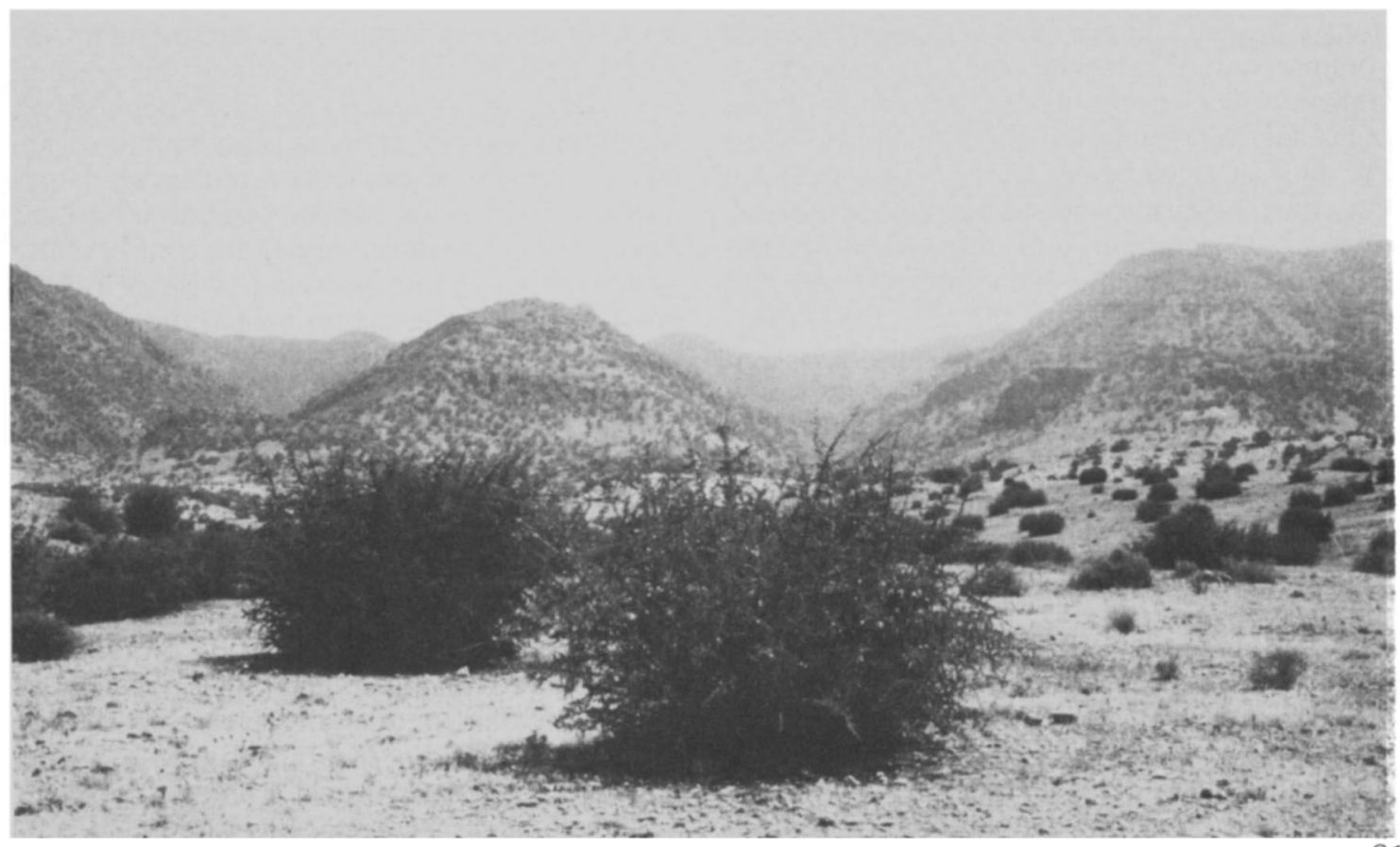

Argan forest destruction in Morocco 
To summarize, the major changes in the natural resources of the Souss Valley have occurred within the last three decades and are continuing today, although the severity of the damage varies from place to place. Thus, most of the slopes of both Atlas ranges are relatively undamaged thanks to the traditional form of land use. Unfortunately such forests are marginal and less complex than the rich lowland forests. Moreover, overgrazing is becoming widespread even in the mountains and damage can already be observed. For example, several forested slopes were felled recently when a new road was constructed to Imouzzer along a valley of great tourist interest. In addition to the aesthetic loss, the removal of the trees has resulted in severe erosion, which has damaged the road itself. The lowland argan forest has been widely devastated with only fragmented and severely threatened patches remaining. It is only along the margin between the plains and the mountain slopes that any high-quality argan forest remains. The fauna has also been seriously affected by the habitat destruction throughout the Souss area. Although there are few data available on the present day status of the fauna, it is known that at least the large herbivores have been exterminated or are highly endangered through poaching. Thus the dorcas gazelle Gazella dorcas, which was still common east of Taroudant only 15 years ago ( $\mathrm{J}$. Ulpiano, pers. comm.) is now extinct there and only a few individuals remain elsewhere in Tiznit Province (A. Ayyad, pers. comm.). Species living in or near the Souss, such as the scimitar-horned oryx Oryx dammah and the Addra gazelle Gazelle dama became extinct many years ago (Cabrera, 1932). In spite of Hirsch's (1981) statement to the contrary, the edmi gazelle G. cuvieri, is virtually extinct in the area and only a few specimens of Barbary sheep Ammotragus laervia survive on the cliffs in the Anezi region (A. Ayyad, pers. comm.).

\section{Conservation in the Souss: problems and proposals}

Few data are available to quantify accurately the extent of the remaining argan forests and the degree of damage suffered. Le Houérou (1981) gave a figure of some $7000 \mathrm{sq} \mathrm{km}$ as the area of argan forests in south-west Morocco, and Goodall and Perry (1979) put the extent at 4000 92 $\mathrm{sq} \mathrm{km}$ in the Souss plain, but neither estimate can be considered reliable. It is known, however, that most of the lowland forest has been destroyed or seriously damaged. Figure 1 gives a tentative picture of the present-day extent and status of the argan forest based on personal experience over the past three years. This large-scale habitat destruction in such a fragile ecosystem poses serious conservation problems. The argan forest has a very low regeneration rate and serious soil erosion and mineral depletion may be expected. Watershed loss may lead to climatic change, with a decrease in the frequency of fogs and an increase in droughts. Prevention of further forest destruction is by far the most important conservation aim in the Souss. Like most other tree species in Morocco, the argan is the responsibility of the government, whether or not it is growing on private or public lands. Nevertheless, both illegal and destructive legitimate logging is taking place everywhere. Public irrigation systems result in large-scale forest destruction, but do not even provide adequate water supplies besides being very costly (Sinclair, 1987). Pastoralism is regarded as an important land-use in the Souss (Le Houérou, 1981) but it can lead to widespread and severe overgrazing. Such forms of land-use should be abandoned and the tradi tional methods re-instituted or expanded (MAB, 1975). Besides controlling logging and grazing, the survival of the argan ecosystem depends on the immediate and efficient preservation of significant blocks of the better remaining larger forests as well as the smaller patches of lowland forest. Some forests are under the control of the government as game reserves (Ait-Baha, Tafinegoult) but public protection is clearly inadequate.

A Massa National Park project (WWF project 3063) has been designed to protect the largest remaining population of the waldrapp Geronticus eremita in the world and the migratory waterfowl at the mouths of the Souss and Massa rivers. The project is being developed by the US Department of the Interior, but the emphasis has been put on tourism with little attention to nature protection. Most of the area to be protected is highly altered rangeland and only small patches of severely damaged argan forests are included in the park (Mellado, Allabou and Alaoui, 1988). Effective conservation of the argan ecosystem requires a general survey of its extent and con-

Oryx Vol 23 No 2, April 1989 
servation status. A catalogue needs to be drawn up of human uses of the area compatible with sustainable development and biological conservation.

\section{Coda}

As Caro (1986) has pointed out, it is difficult to convince others of the merits of wildlife conservation, but international pressure must try to persuade the Moroccan Government not to destroy its outstanding natural heritage through anarchic exploitation (Fennane, Barbero and Quezel, 1984). Words will not suffice, and money must be provided to compensate in some way the people for whom nature conservation may deplete the already low standard of living. I regret the short-sighted conservation policy being developed by the US Government via a network of preserved areas throughout Morocco. This policy is based on short-term gains (tourism) rather than on long-term goals of conservation and sustainable development for the welfare of the Moroccan people.

\section{Acknowledgments}

This study was supported with funds of the International Technical Co-operation of the Spanish Foreign Office. I thank Mr Julio Ulpiano and family for their hospitality at Ouled Abdellah and Agadir, while remaining in the Souss valley. Lola Sanchez and Miguel Ulpiano helped me with the field work whereas the latter and his father (J. Ulpiano) told me much of the history of forest destruction in the Souss over the last three decades reported here. I also thank $\mathrm{Dr}$ S. K. Eltringham, who kindly provided useful comments and revised the English style.

\section{References}

Badia y Leblich, D. 1814. Voyages d'Ali-Bey el Abassi en Afrique et en Asie. Paris (Old copy without editor and pagination references).

Bons, J. 1967. Recherches sur la biogéographie et la biologie des amphibiens et des reptiles du Maroc. Thèse Université de Montpellier. $321 \mathrm{pp}$. Montpellier.

Cabrera, A. 1932. Los mamiferos de Marruecos. Trabajos del Museo de Ciencias Naturales, 57, 361 pp. Madrid.

Caro, T.M. 1986. The many paths to wildlife conservation in Africa. Oryx, 20, 221-229.
Di Castri, F. Goodall, D.W.G. and Specht, R.L. 1981. Ecosystems of the World, II. Mediterranean-Type Shrublands. Elsevier, Amsterdam. 643 pp.

Evenary, M., Noy-Meyr, I. and Goodall, D.W. 1986. Ecosystems of the World 12B. Hot Deserts and Arid Shrublands, $B$. Elsevier, Amsterdam. 451 pp.

Fennane, M., Barbero, M. and Quezel, P. 1984. Le thuya de Berberie au Maroc: aperçu phytogéographique et écologique. Bulletin de 'Institut Scientifique, 8, 115134.

Goodall, D.W. and Perry, R.A. 1979. Arid Land Ecosystems: Structure, Functioning and Management, 1. 881 pp. Cambridge University Press, Cambridge.

Hirsch, U. 1981. Avant-projet de création du Parc National de Massa, Royaume du Maroc. Rapport Technique inédit. $74 \mathrm{pp}$.

Le Houérou, H.N. 1981. Impact of man and his animals on mediterranean vegetation. In Ecosystems of the World, 11. Mediterranean-Type Shrublands (eds F. di Castri, D.W. Goodall and R.L. Specht), pp. 479-517. Elsevier, Amsterdam.

MAB, 1975. Programme sur l'aménagement écologique des parcours arides et semi-arides d'Afrique et du Proche et du Moyen-Orient (EMASAR) de la FAO. Rapport 30, 57 pp. Unesco, Paris.

$\mathrm{MAB}, 1976$. Forêt et maquis méditerranéens: écologie, conservation et aménagement. Note technique $2.84 \mathrm{pp}$. Unesco, Paris.

Mellado, J., Allabou, A. and Alaoui, B. 1988. L'herpetofaune du projet de Parc National du Massa (Agadir, Maroc): un aperçu ëcologique et ses implications dans le dëveloppment du plan d'aménagement. Acta Oecologia Applicata, 9, 55-74.

Peltier, J.P. 1976. La vegetation du Haut Souss. De la cuvette d'Aouzioua au jbel n'Bougzoul. Bulletin de l'Institut Scientifique, 1, 119-145.

Peltier, J.P. 1977. La vègètation du massif du Kerdous (AntiAtlas occidental). Bulletin de l'Institut Scientifique, 2, 5 32.

Posner, S.D. 1986. Vegetation in the Proposed Gazelle Reserves, Massa National Park Project. Unpublished technical report. $75 \mathrm{pp}$.

Sauvage, C. and Vindt, J. 1952. Flore du Maroc 1. Travaux de l'Institut Scientifique Chérifien, 4, 148 pp. Tanger.

Sinclair, L. 1987. Government irrigation subsidies result in huge economic and environmental losses worldwide. Ambio, 16, 149-151.

Valverde, J.A. 1957. Aves del Sahara Español (Estudio ecológico del desierto). $487 \mathrm{pp}$. Instituto de Estudios Africanos, Madrid.

Jesús Mellado, Estación Experimental de Zonas Aridas, General Segura, 1, 04001-Almeria, Spain. 